\title{
Effect of an acute exposure of rat testes to gamma rays on germ cells and on Sertoli and Leydig cell functions
}

\author{
G Pinon-Lataillade ${ }^{1 *}$, MC Viguier-Martinez ${ }^{2}$, \\ AM Touzalin 3, J Maas 1 , B Jégou ${ }^{3}$ \\ ${ }^{1}$ Commissariat à l'Énergie Atomique, DSV/DPTE/Laboratoire de Radiotoxicologie, \\ BP No 12, 91680 Bruyères-le-Châtel; \\ 2 Laboratoire de Neuroendocrinologie, Faculté des Sciences, Parc de Grandmont, 37200 Tours \\ et INRA, Station de Physiologie de la Reproduction, 37380 Nouzilly; \\ 3 Groupe d'Étude de la Reproduction chez le Mâle (GERM), URA CNRS 256, \\ Université de Rennes I, Campus de Beaulieu, 35042 Rennes Cedex, France
}

(Received 25 March 1991; accepted 19 August 1991)

\begin{abstract}
Summary - Germ cells and Sertoli and Leydig cell functions were studied from 7 to 180 days after an acute exposure of 2-month-old rat testes to 9 Gy of $\gamma$ rays. Body weight, testis and epididymal weights were recorded. Sertoli cell parameters (androgen-binding protein, ABP, in caput epididymis and plasma follicle stimulating hormone, FSH) and Leydig cell parameters (plasma luteinizing hormone, LH, testosterone and prostate and seminal vesicle weights) were determined together with the number of germ cells and Sertoli cells. Irradiation did not affect body weight but significantly reduced testicular and epididymal weights from day 7 and day 15 post-irradiation respectively. The cells killed by irradiation were mainly spermatogonia and preleptotene spermatocytes engaged in replicating their DNA at the time of exposure, but all spermatocytes seemed damaged as they gave abnormal descendent cells. By day 34 , only elongated spermatids remained in a few tubules and thereafter very little regeneration of the seminiferous epithelium occurred, except for one rat which showed a better regeneration. Levels of ABP decreased by day 15 when the germ cell depletion had reached the pachytene spermatocytes, whereas FSH and LH levels rose when the number of elongated spermatids decreased. Levels of testosterone and the weight of the seminal vesicles did not change; occasionally, the prostate weight was slightly reduced. These results support our hypothesis that pachytene spermatocytes and elongated spermatids are involved in influencing some aspects of Sertoli cell function in the adult rat.
\end{abstract}

irradiation / rat / spermatogenesis / Sertoli cells / Leydig cells

Résumé - Effet d'une irradiation $\gamma$ aiguë du testicule de rat sur les cellules germinales et les fonctions sertolienne et leydigienne. Des rats âgés de 2 mois ont subi une irradiation $\gamma$ aiguë de 9 Gy localisée au niveau des testicules. L'effet de l'irradiation sur les cellules germinales, les fonctions sertolienne et leydigienne a été étudié $d u 7^{\theta}$ au $180^{\circ} j$ après l'irradiation. Nous avons suivi l'évolution

* Correspondence and reprints. 
pondérale des animaux, de leurs testicules et de leurs épididymes. Les paramètres sertoliens (ABP dans la tête de l'épididyme et FSH plasmatique) et les paramètres leydigiens (LH et testostérone plasmatiques, poids de la prostate et des vésicules séminales) ont été déterminés en même temps que le nombre des cellules germinales et des cellules de Sertoli. L'irradiation n'a pas affecté le poids des animaux mais a entraîné une diminution significative du poids des testicules et des épididymes à partir $d u 7^{\circ}$ et du $15^{\circ}$ j post-irradiation, respectivement. Les cellules tuées par l'irradiation ont été essentiellement les spermatogonies et les spermatocytes au stade préleptotène, en phase de replication $d^{\prime} A D N$. De plus, toutes les catégories de spermatocytes ont très probablement été endommagées puisque les cellules de leur descendance présentent des anomalies. 34 j après lirradiation, seules subsistent des spermatides allongées dans quelques sections de tubes séminifères. Une très faible régénération de l'épithélium séminifère s'est produite sauf pour un animal où cette régénération a été plus importante. Les niveaux d'ABP ont été réduits dès $1 e 1^{\circ} \mathrm{j}$, au moment où le nombre des spermatocytes au stade pachytène décline. En revanche, les niveaux de FSH et LH ne s'élèvent que lorsque diminue le nombre des spermatides allongées. Le niveau de testostérone plasmatique et le poids des vésicules séminales n'ont pas changé tandis que le poids de la prostate a parfois légèrement diminué. Ces résultats confirment notre hypothèse selon laquelle les spermatocytes au stade pachytène et les spermatides allongées seraient impliqués dans le contrôle de certains aspects de la fonction sertolienne chez le rat adulte.

irradiation / rat / spermatogenèse / cellule de Sertoll / cellule de Leydig

\section{INTRODUCTION}

The irradiated testis of the adult rodent has been often used to study germ cell radiosensitivity (Oakberg and $\mathrm{Di}$ Minno, 1960; Erickson, 1976; Van Beek et al, 1986) and spermatogonial renewal and differentiation (Huckins, 1978; Huckins and Oakberg, 1978; Meistrich et al, 1978). Spermatogonia are known to be the most radiosensitive cells in the testis, but if the radiation dose is higher, more differentiated cells can also be destroyed (Shaver, 1953; Oakberg and Di Minno, 1960). Although the number of Sertoli cells remains unchanged following irradiation, reports on their function are contradictory (Cunningham and Huckins, 1978; Hopkinson et al, 1978; Main et al, 1978; Wang et al, 1983; Pinon-Lataillade et al, 1985; 1988; Delic et al, 1986; Kamtchouing et al, 1988; Pineau et al, 1989).

Testicular function is controlled by: 1) hormones secreted by the pituitary, such as luteinizing hormone (LH) which influences spermatogenesis by stimulating testosterone biosynthesis by Leydig cells, and follicle stimulating hormone (FSH) which exerts a selective action on the Sertoli cells within the seminiferous tubules (Risbridger et al, 1981a); and 2) an intragonadal paracrine regulatory system involving germ cells, Sertoli cells, Leydig cells and peritubular cells (Parvinen, 1982; Sharpe, 1986; Jégou et al, 1988; Verhoeven and Cailleau, 1989).

Within the seminiferous tubules, Sertoli cells have been shown to influence germ cell differentiation, development and metabolism and there is growing evidence that germ cells in turn may influence Sertoli cell function (Jégou et al, 1988). One possible approach to the investigation of this complex aspect of the paracrine regulation of spermatogenesis has been to use different protocols of irradiation which, in vivo, were found to induce different degrees of seminiferous epithelium modifica- 
tion (Rich and De Kretser, 1977; Hopkinson et al, 1978; Vihko et al, 1984; PinonLataillade et al, 1985, 1988; Pineau et al, 1989; Kangasniemi et al, 1990a, b). Depending on whether irradiation was delivered chronically at low dose rate, or acutely at different total doses, the type and number of cells destroyed in the testis were different. Therefore, as the result of the development of what is called the maturation depletion process (Dym and Clermont, 1970), various germ cell associations in the seminiferous epithelium were altered depending on time, during exposure to chronic irradiation or after exposure to acute irradiation. The relationship between these associations and Sertoli cell function, as well as Leydig cell function, were then investigated.

In the present study, we further investigated the paracrine control of testicular function. Accordingly, rat testes were irradiated locally with a single dose of $\gamma$ rays and the animals were killed at various times after irradiation. We report histological study of the seminiferous epithelium together with the corresponding parameters of Sertoli cell function, ie: the levels of androgen-binding protein (ABP) and of plasma FSH, which indirectly and partially reflects inhibin production (Setchell et al, 1977; Weinbauer et al, 1989), as well as several Leydig cell parameters such as accessory sex organ weight and plasma testosterone and LH concentrations.

\section{MATERIALS AND METHODS}

\section{Animals and irradiation procedure}

Ninety-six 2-month-old Sprague-Dawley rats (IFFA-CREDO France) were used. The animals were randomly allocated to control or irradiated groups. Irradiated rats were restrained in cylindrical boxes and positioned so that only the testes and surrounding organs were exposed to a collimated yray beam. Control rats were sham-irradiated. The total dose of $9 \mathrm{~Gy}$ from ${ }^{60} \mathrm{Co}$ source was delivered in $3 \mathrm{~min}$. The dose was measured with a tissue equivalent chamber type Victoreen $\mathbf{4 1 5}$ dosimeter.

Control and irradiated animals were kept under controlled temperature and lighting conditions (12 $h$ dark, $12 \mathrm{~h}$ light). They were given standard dry pellets and tap water ad libitum. Groups of 6 irradiated rats and age-matched controls were killed by decapitation $7,15,23$, $34,50,71,118$ and 180 days after irradiation. Their testes, epididymides, ventral prostate and seminal vesicle glands were immediately dissected out and weighed. Testes were processed for histological estimation and the epididymides were immediately frozen in liquid nitrogen and stored at $-20^{\circ} \mathrm{C}$ until $\mathrm{ABP}$ assay. Blood samples were collected from the neck and plasma was frozen at $-20^{\circ} \mathrm{C}$ until radioimmunoassay for FSH, LH and testosterone.

\section{Testicular histology}

The left testis of each rat was fixed in BouinHollande solution and embedded in paraffine. Five- $\mu \mathrm{m}$ sections were stained by Feulgen reaction. The cycle of the seminiferous epithelium was classified in the 14 stages described by Leblond and Clermont (1952) for the rat. A qualitative estimation of the number of germ cells was made at all stages, and quantitative estimations of germ cells and Sertoli cells with nuclei containing a visible nucleolus (Erickson and Martin, 1973) were made on 20 tubular cross-sections at stage VII. In tubules depleted of germ cells from day 50 to 180 , only the numbers of A spermatogonia and Sertoli cells were counted in $\mathbf{5 0}$ tubular cross-sections taken at random.

To take account of volume and tissue shrinkage, due to histological processing and to the depopulation of the tubules by irradiation, cell numbers were expressed for the total length of the seminiferous tubules, which was calculated as previously described (Hochereau-de Reviers and Lincoln, 1978). The diameter of these tubules was measured on 20 cross-sections per testis using an ocular micrometer. For each testis the relative volume of the intertubular tissue and seminiferous tubules was determined with a 
20 point ocular integrator on 40 microscope fields. No Abercrombie's correction (Abercombie, 1946) was made for A spermatogonia, Sertoli cells and for elongated spermatids as none of these cells have round nuclei, neither was any correction made for early spermatids because irradiation gave them various sizes and shapes. The results were expressed as percentages of control values.

\section{Hormonal measurements}

Plasma samples were analysed for $\mathrm{FSH}$ and $\mathrm{LH}$ contents using specific double antibody radioimmunoassays as previously described (ViguierMartinez, 1976). The results were expressed in terms of NIDDK rat FSH RP-1 for FSH, and purified rat $L H S X 1-1$ for $L H$. One unit of $L H S X \times 1-1$ was equivalent to $1.58 \mathrm{U}$ of NIDDK-LH-S11. The detection limits were $100 \mathrm{ng} / \mathrm{ml}$ for $\mathrm{FSH}$ and $0.6 \mathrm{ng} / \mathrm{ml}$ for $\mathrm{LH}$, and the intra-assay coefficient of variation was $10 \%$ for both.

Plasma testosterone was measured after solvent extraction using a previously described radioimmunoassay (Viguier-Martinez et al, 1983). The intra-assay coefficient of variation was $6 \%$ and the detection limit $50 \mathrm{pg} / \mathrm{ml}$.

\section{ABP assay}

Several previous studies have demonstrated that measurement of ABP in the caput epididymidis provides a very suitable and reliable index of Sertoli cell function (Tindall et al, 1975; Hansson et al, 1978). Accordingly, caput epididymides were thawed and then homogenized in cold buffer containing $10 \mathrm{mM}$ Tris- $\mathrm{HCl}, 1.5 \mathrm{mM}$ EDTA, $1.0 \mathrm{mM} 2-\beta$ mercaptoethanol and $10 \%$ glycerol (v/v), pH 7.4 (TEMG). Homogenates were centrifuged at $105000 \mathrm{~g}$ for $1 \mathrm{~h}$ at $0^{\circ} \mathrm{C}$. $A B P$ was measured using the steady state polyacrylamide gel electrophoresis method of Ritzen et al (1974) with some modifications (PinonLataillade et al, 1988). The results were expressed as pmol of ABP per organ.

\section{RESULTS}

\section{Body, testicular and epididymal welghts}

After irradiation, the mean body weight $( \pm$ SEM) of the animals increased throughout the experiment and was not significantly different from the mean body weight of the age-matched controls (table 1). Testis weight declined to $85 \%$ of the control value by day $7(P<0.01)$ and then dropped to $58 \%$ of the control value by day 23 and to $41 \%$ by day $34(P<0.001)$. No significant recovery of testis weight was observed thereafter (table I).

After irradiation, epididymal weight decreased to $88 \%$ of the control value by day $15(P<0.01)$ and to $63 \%$ by day $50(P<$ $0.001)$. Thereafter, it formed a plateau at $\approx$ $55 \%$ of the control value (table I).

\section{Histological analysis}

By day 7 post-irradiation, the seminiferous epithelium was devoid of differentiating (A1 to B) spermatogonia and of preleptotene and leptotene spermatocytes. By this time also, only $11 \%$ of the spermatogonial population (stem celis) remained at stage VII (fig 1) whereas the few zygotene spermatocytes still present were degenerating (stages XII-XIII). Number of pachytene spermatocytes were greatly reduced only at stages II-III and IV of the cycle. Round spermatids at steps 1 to 7 of spermiogenesis which derived from irradiated pachytene spermatocytes exhibited an abnormally large size range and elongated spermatids at steps 8 to 19 of spermiogenesis displayed normal shape. 


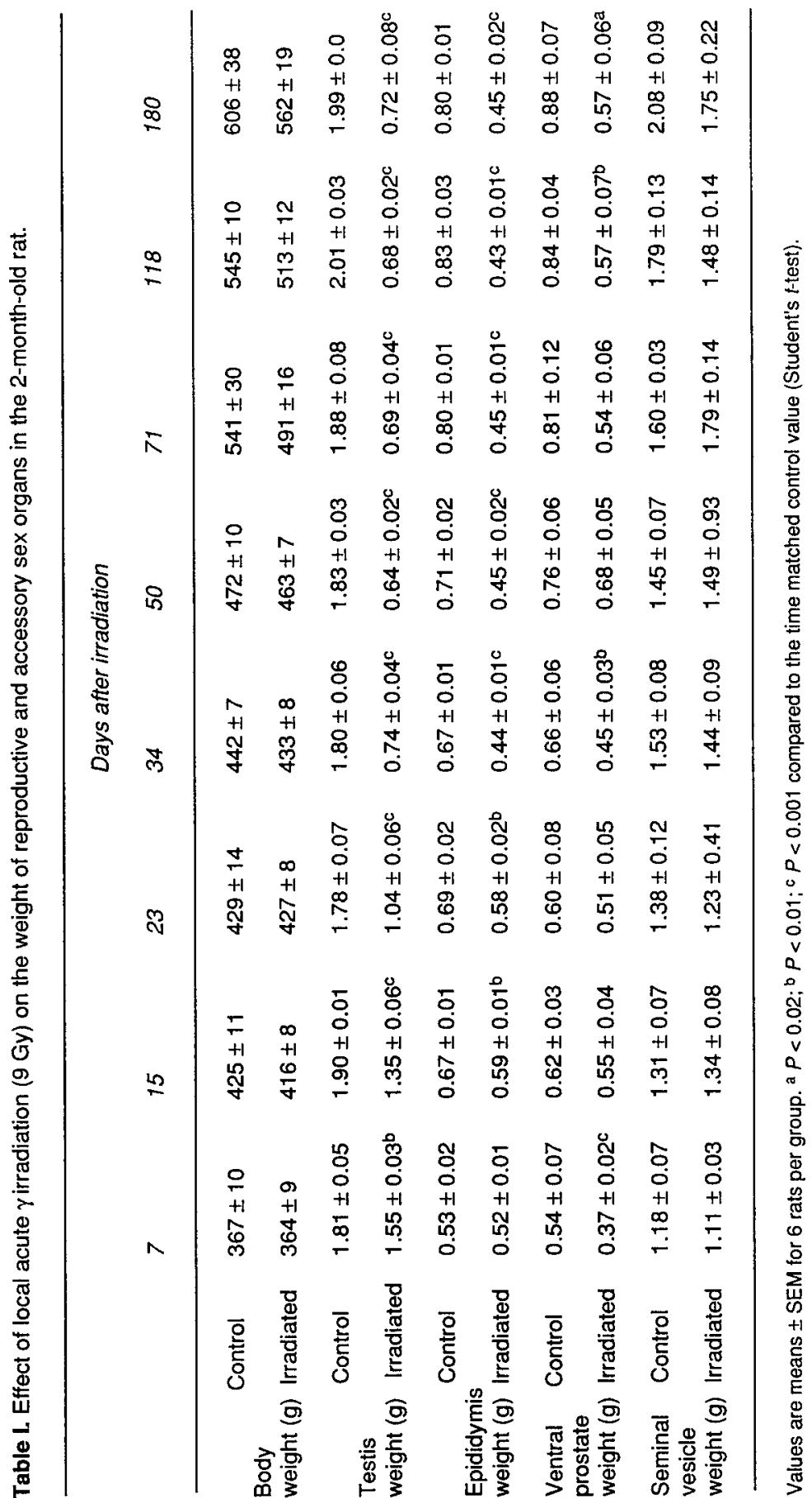




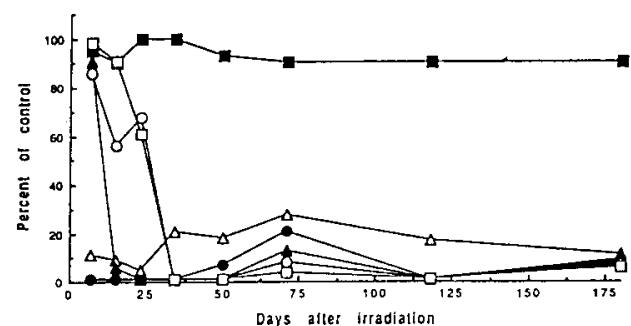

Fig 1. Temporal changes in the number of Sertoli and germ cells at stage (VII) after acute testicular $\gamma$-irradiation of rats of 2 months of age. $-\Delta-$ : spermatogonia $\left(A_{1}+A_{0}\right) ;-\longrightarrow$ : preleptotene spermatocytes; - $\mathbf{A}$-: pachytene spermatocytes; - - - round spermatids; $-\square-$ : elongated spermatids: and - - - Sertoli cells. Error bars were omitted for clarity.

By day 15 , only pachytene spermatocytes at stages VIII-IX-X, diplotene spermatocytes at stage XIII and secondary spermatocytes at stage XIV were seen. Number of pachytene spermatocytes were greatly reduced at stages XI-XII. Spermatids were still present but they show abnormalities in size range (round spermatids) and in head shape (elongated spermatids). The number of late spermatids at stage VII was $90 \%$ of normal value (fig 1 ).

By day 23, the spermatocytes had completely disappeared from the seminiferous epithelium (fig 1). Only spermatids in steps 4,5 and from early-step 7 to 19 with abnor- mal nuclei were visible (fig 2B). Furthermore, abnormality in the release of spermatozoa into the lumen was also noted (mature spermatozoa were still seen close to the basement membrane instead of being released into the lumen, fig $2 \mathrm{C}$ ) and certain cells, probably spermatogonia, were seen degenerating. By day 23 , the spermatogonial population at stage VII was estimated to be $5 \%$ of the control value but the number of Sertoli cells was still unchanged (fig 1). Spermatid nuclear morphology was abnormal (fig 2B-C). At stage VII the number of round and elongated spermatids represented 68 and $61 \%$ of the control values respectively (fig 1 ).

By day 34 , only elongated spermatids were still present in some tubules and by day 50 they had completely disappeared. At this time, a large proportion of tubules seen in cross section contained only Sertoli cells but a few tubules exhibited reduced regeneration and contained small colonies of spermatogonia and spermatocytes (fig $2 D)$ and the number of spermatogonia $\left(A_{1}\right.$ $+A_{0}$ ) at stage VII corresponded to $21 \%$ of the control value. Thereafter, as shown in figure 1 , from days 50 to 180 , the Sertoli cell number in the irradiated animals was not significantly different from the Sertoli cell number in the controls. The regeneration of the seminiferous epithelium remained very low, except for 1 of the 6 animals killed at day 180. In this animal, the number of elongated spermatids at stage

Fig 2.A: Control rat illustrating normal seminiferous epithelium at stage VII (Feulgen, $\times 1$ 000) comprising Sertoli cells $(-$ ) A type spermatogonia $(-)$, preleptotene spermatocytes $(\rightarrow)$, pachytene spermatocytes $(P)$, round spermatids $(R)$ and elongated spermatids step $19(E)$. B: 23 days after irradiation, the stage VII of the seminiferous epithelium (Feulgen, $\times 1000$ ) was devoid of spermatogonia, preleptotene and pachytene spermatocytes; round spermatids with various sizes were observed $(-)$. C: Note at stage VIII-IX, 23 days after irradiation the absence of preleptotene and pachytene spermatocytes and the abnormal shape of the round $(-)$ and elongated spermatids step 19 ( - ); some of them are seen deep within the seminiferous epithelium $\rightarrow$ next to the limiting membrane of the tubule (Feulgen, $\times 1$ 000). D: 50 days after irradiation, tubules containing Sertoli cells (-) were observed, and in a few case small colonies of spermatogonia and spermatocyte cells $(-; x 200)$. 

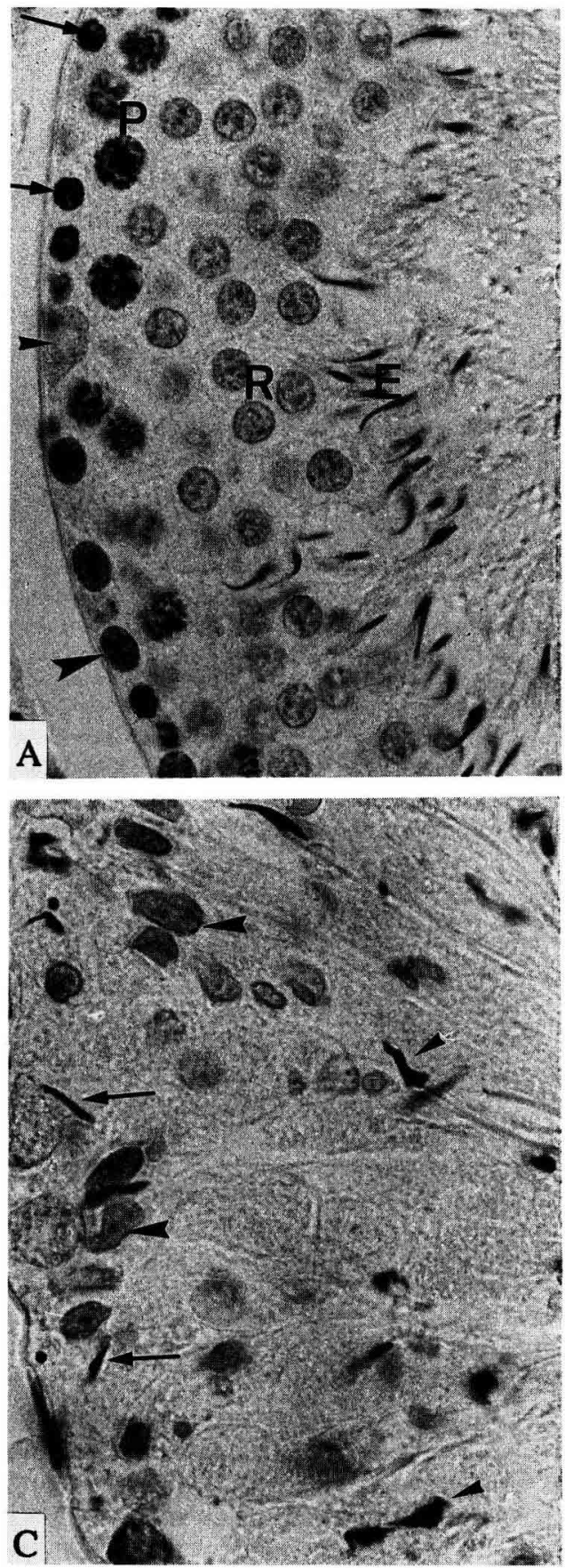
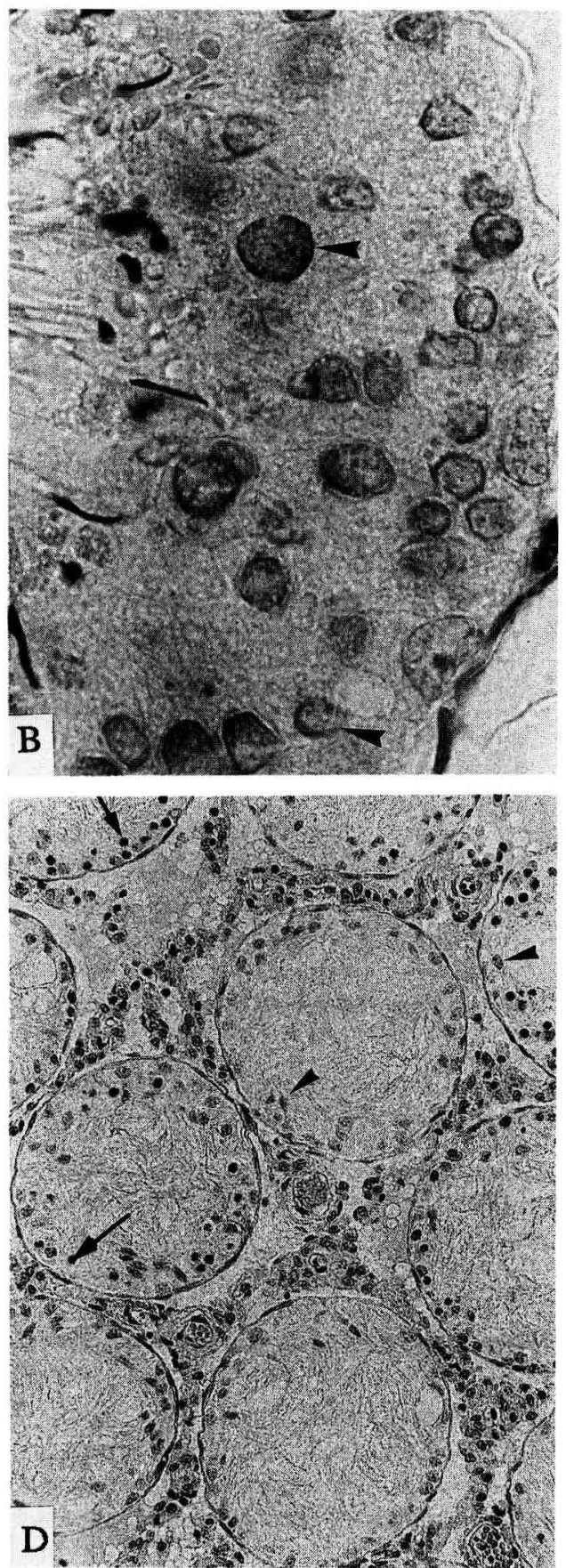

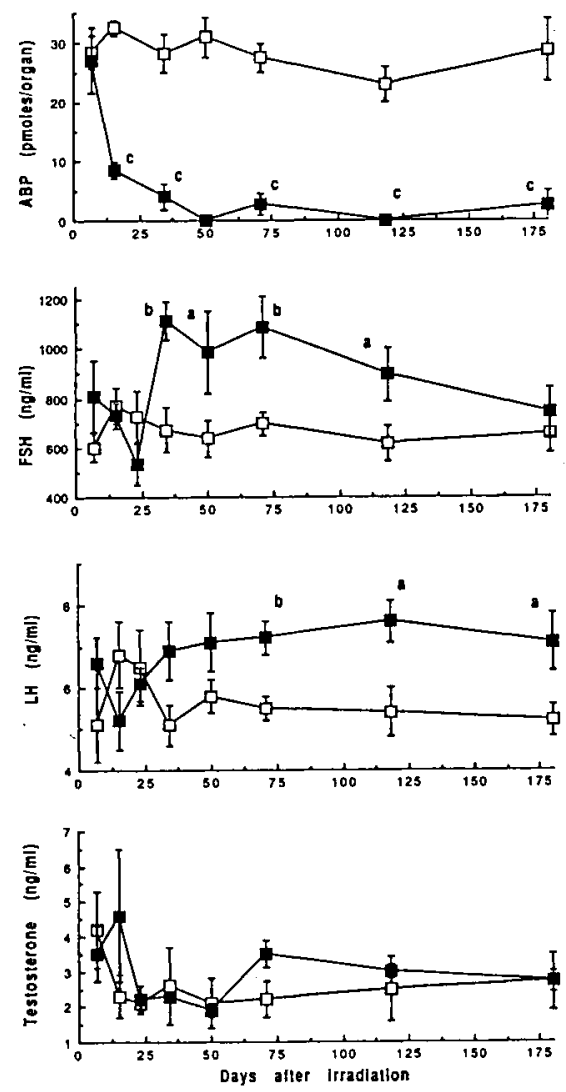

Fig 3. Effect of acute testicular $\gamma$-irradiation on $A B P$ content in caput epididymis (pmol per organ) and on plasma FSH (rat FSH-RP-1) standard), LH (rat LH-SX1-1 standard), testosterone concentrations in the 2-month-old rats ( $-\square-$ control rats, $\longrightarrow$ - irradiated rats). Values are means \pm SEM for 6 rats per group, a: $P<0.05$; b: $P<0.01$; c: $P<0.001$.

VII was estimated at $\approx 35 \%$ of the control value.

A significant decrease in seminiferous tubule diameter was noted: it was slightly reduced to $88 \%$ of the control value by 15 days and by day 34 it had dropped to $69 \%$ of this value. From day 50 until the end of the experiment, it plateaued at $\approx 60 \%$ of the control value.

\section{ABP levels}

As early as day 15 after irradiation, epididymal content ABP has dropped to $26 \%$ of the control value $(P<0.001)$ and by day 34 it was only $14 \%$ of this value. From day 50 to the end of the experiment, the ABP level remained below $10 \%$ of the control level (fig 3).

\section{Hormonal measurements}

\section{Plasma FSH levels}

No significant change in FSH levels was found until day 23. From days 34 to 118 , these levels rose significantly. At the end of the experiment (day 180), due to a particularly low value of $\mathrm{FSH}$ level in one animal, the average FSH level in the irradiated group, although still higher than in the control group, was not significantly different (fig 3).

\section{Plasma LH and testosterone levels}

Plasma LH levels rose after day 34 but this increase was only significant from day 71 and remained so until the end of the experiment (fig 3).

No significant change was observed throughout the experiment in the weights of the seminal vesicles (table I) or in the concentrations of plasma testosterone (fig 3). It must, however, be noted that the weight of the ventral prostate was sometimes smaller in irradiated animals than in the controls (table 1); a significant fall in this organ was only observed at $7(P<$ 
$0.001), 34,118(P<0.01)$ and $180(P<$ 0.02 ) days post-irradiation.

\section{DISCUSSION AND CONCLUSION}

Following local exposure of rat testes to an acute dose of $\gamma$ rays ( $9 \mathrm{~Gy}$ ), the spermatogonia and the preleptotene spermatocytes, which at that time were replicating their DNA, were the main classes of cells destroyed. Radiation damage to differentiating spermatogonia led, by day 7 , to the disappearance of all preleptotene and leptotene spermatocytes and to a dramatic reduction in the number of zygotene spermatocytes. At day 7 post-irradiation also, as a result of killing of the preleptotene spermatocytes in S phase at stages VII and VIII, a marked decrease in the number of pachytene spermatocytes occurred at stages II-III and IV; this decrease had progressed to stages XI-XII by day 15 and to steps 6 and early 7 spermatids by day 23 . The time course of the progression of this "gap" indicates that the kinetics of spermatogenesis are unchanged after moderate irradiation, as previously observed by Dym and Clermont (1970). By day 7 only $11 \%$ of the spermatogonial population remained at stage VII compared to the control value. As number of $A_{1}$ spermatogonia was reduced to < $1 \%$ with 6 Gy (Erickson, 1976), these surviving spermatogonia were probably undifferentiated stem spermatogonia. This is in agreement with the data of Huckins (1978) who found that only $11 \%$ of spermatogonia (stage VII), representing the stem cells, survived after a 3 Gy irradiation. The fact that the number of these surviving spermatogonia decreased with time $(5 \%$ at day 23$)$ indicates that some of them were probably injured and that they subsequently died when they became mitotically active, while the others allowed re- generation of the epithelium in a few tubules.

It is noteworthy that abnormalities were observed in the nuclei of spermatids as early as 7 days post-irradiation for round spermatids and 15 days post-irradiation for elongated spermatids. This demonstrates that $\gamma$ rays damaged all types of spermatocytes whose division during the meiotic process resulted in abnormal descendent cells. This agrees with previous observations in the mouse (Oakberg and Di Minno, 1960) and rat (Shaver, 1953) for doses of $X$-rays higher than 5 Gy. In our experiment, most of the seminiferous tubules only contained Sertoli cells after day $\mathbf{5 0}$. From then, although a few tubules displayed small groups of spermatogenic cells, little regeneration of the seminiferous epithelium occurred during the 180-day observation period, as shown by others after exposure to high doses of irradiation (Shaver, 1953; Meistrich et al, 1978; Delic et al, 1986). As the maturation depletion of germ cells reached the pachytene spermatocytes (day 15), significant decreases were observed in seminiferous tubule diameter and testicular and epididymal weights.

The number of Sertoli cells did not significantly change throughout the experiment; at day 7 their function was not affected, despite a considerable decrease in the numbers of spermatogonia and of preleptotene, leptotene and zygotene spermatocytes as previously shown (Wang et al, 1983; Pinon-Lataillade et al, 1985, 1988; Kamtchouing et al, 1988; Pineau et al, 1989). However, by day 15 postirradiation, ABP content was decreased by $74 \%$ when the maturation depletion process had reached the pachytene spermatocytes, and the number of early spermatids had slightly declined. By day 34 , when the number of late spermatids had 
dropped, ABP content was further reduced and $\mathrm{FSH}$ levels increased.

There are several pieces of evidence demonstrating in vivo and in vitro that a paracrine regulation of Sertoli cells by germ cells exists (Galdieri et al, 1984; Jégou et al, 1984, 1988; Le Magueresse and Jégou, 1988; Le Magueresse et al, 1986, 1988; Djakiew and Dym, 1988; Bartlett et al, 1988; Kangasniemi et al, 1990a, b). Thus, in vivo, it clearly appears that elongated spermatids are implicated in the secretion of inhibin and ABP by Sertoli cells (Main et al, 1976; Jégou et al, 1984; Pineau et al, 1989). The possible implication of pachytene spermatocytes in the paracrine regulation of the Sertoli cell function has also been suggested (in vitro: Galdieri et al, 1984; Le Magueresse et al, 1986, 1988; Djakiew and Dym, 1988; in vivo: Pinon-Lataillade et al, 1985; Bartlett et al, 1988). It is noteworthy that in our previous studies using continuous low dose-rate $\gamma$ irradiation, the effects of the decrease in the number of pachytene spermatocytes on Sertoli cell parameters (serum FSH and $A B P$ levels) were not always significant (Pinon-Lataillade et al, 1985, 1988; Pineau et al, 1989). This might indicate that contrary to the acute exposure to 9 Gy of $\gamma$ rays used here, such irradiation which causes a slow decrease in the number of the different germ cells might allow the Sertoli cells or other germ cell types which influence Sertoli cells to compensate in varying degrees for the loss of pachytene spermatocytes. It is interesting to note that Sertoli cell function was impaired when the number of elongated spermatids was reduced. This highlights the particular importance of this category of germ cell in influencing Sertoli cell function.

Whether or not Leydig cells are damaged after irradiation remains controversial (Rich et al, 1979; Cunningham and Huckins, 1978; Wang et al, 1983; Delic et al,
1986). According to Wang et al (1983), the concentration of testosterone produced in the immediate environment of the Leydig cells was not affected following $X$-ray exposure. However, the same authors have observed that the decrease in testicular blood flow induced by irradiation can lead to a slight decrease in the total amount of testosterone entering the general circulation. In the present study in which $\gamma$ rays were used in the same way as $X$-rays in previous studies (Hopkinson et al, 1978; Main et al, 1978; Delic et al, 1986), plasma $\mathrm{LH}$ concentrations were found to increase significantly, whereas neither plasma testosterone levels nor the weights of the seminal vesicles changed significantly. Nevertheless the weight of the ventral prostate was occasionally decreased. This most probably results from the direct exposure of this organ to the $\gamma$ rays since this decrease occurred as early as day 7 postirradiation, that is, before any change in hormone level was seen. The absence of a rise in plasma testosterone corresponding to the rise in plasma $\mathrm{LH}$, frequently observed after tubule damage, has sometimes been attributed to a loss of Leydig cells (Delic et al, 1986), but has more often been considered to result from the changes induced in the cell-to-cell interactions between the seminiferous tubules and the interstitial compartment (Risbridger et al, 1981b).

In conclusion, these results show that a local 9 Gy $\gamma$-irradiation of the rat testes nearly suppressed spermatogenesis. This irradiation protocol leads to an increase of $\mathrm{LH}$ and $\mathrm{FSH}$ plasma levels as usual after severe testicular damage, without any change in plasma testosterone levels. When combined with the data in the literature these results further support the hypothesis that elongated spermatids and possibly pachytene spermatocytes control the production of $A B P$ and inhibin by Sertoli cells in the adult rat testis. 


\section{ACKNOWLEDGMENTS}

This work was supported by funds from the Direction des Recherches, Études et Techniques de la Délégation Générale pour l'Armement (DRET; Grant 87-1323), the Institut de Protection et Sûreté Nucléaire du Commissariat à I'Energie Atomique, the Institut National de la Santé et de la Recherche Médicale (Grant 874010), the Fondation de la Recherche Médicale, the Fondation de France and the Comite d'llleet-Vilaine de la Ligue Nationale Française de Lutte contre le Cancer. Rat FSH radioimmunoassay kit, testosterone anti-serum, purified LH SX $1-1$ and rat LH antiserum were generously supplied by NIDDK (Bethesda, MD), G Picaper, $M$ Jutisz and $M$ Dubois respectively. We wish to thank $M$ Veaux, JM Reboux and $P$ Leflèche for skilled technical assistance.

\section{REFERENCES}

Abercrombie M (1946) Estimation of nuclear population from microtome sections. Anat Rec 94, 239-247

Bartlett JMS, Kerr JB, Sharpe RM (1988) The selective removal of pachytene spermatocytes using methoxy acetic acid as an approach to the study in vivo of paracrine interactions in the testis. $J$ Androl 1, 31-40

Cunningham GR, Huckins $C$ (1978) Serum FSH, $\mathrm{LH}$ and testosterone in ${ }^{60} \mathrm{Co}$ y-irradiated male rats. Radiat Res 76, 331-338

Delic JI, Hendry JH, Morris ID, Shalet SM (1986) Dose and time relationships in the endocrine response of the irradiated adult rat testis. $J$ Androl 7, 32-41

Djakiew D, Dym M (1988) Pachytene spermatocyte proteins influence Sertoli cell function. Biol Reprod 39, 1193-1205

Dym M, Clermont $Y$ (1970) Role of spermatogonia in the repair of the seminiferous epithelium following X-irradiation of the rat testis. $A m$ $J$ Anat 128, 265-282

Erickson BH (1976) Effect of ${ }^{60} \mathrm{Co} \gamma$ radiation on the stem and differentiating spermatogonia of the postpuberal rat. Radiat Res 68, 433-448

Erickson BH, Martin PG (1973) Influence of age on the response of rat stem spermatogonia to $\gamma$ irradiation. Biol Reprod 8, 607-612
Galdieri M, Monaco L, Stefanini M (1984) Secretion of androgen binding protein by Sertoli cells is influenced by contact with germ cells. $J$ Androl 5, 409-415

Hansson V, Purvis K, Attramadal A, Torjersen P. Andersen D, Ritzén EM (1978) Sertoli cell function in the androgen insensitive (TFM) rat. Int J Androl 1, 96-104

Hochereau-de Reviers MT, Lincoln GA (1978) Seasonal variation in the histology of the testis of the red deer, Cervus elaphus. J Reprod Fertil 54, 209-213

Hopkinson CRN, Dulisch B, Gauss G, Hilscher W, Hirschlauser C (1978) The effect of local testicular irradiation on testicular histology and plasma hormone levels in the male rat. Acta Endocrinol 87, 413-423

Huckins C (1978) Behavior of stem cell spermatogonia in the adult rat irradiated testis. Biol Reprod 19, 747-760

Huckins C, Oakberg EF (1978) Morphological and quantitative analysis of spermatogonia in mouse testes using whole mounted seminiferous tubules. II. The irradiated testes. Anat Rec 192, 529-542

Jégou B, Laws AO, de Kretser DM (1984) Changes in testicular function induced by short-term exposure of the rat testis to heat: further evidence for interaction of germ cells, Sertoli cells and Leydig cells. Int J Androl 7, 244-257

Jégou $B$, Le Magueresse $B$, Sourdaine $P$, Pineau C, Velez de la Calle JF, Garnier DH, Guillou F, Boisseau C (1988) Germ cell-Sertoli cell interactions in vertebrates. In: Molecular and Cellular Endocrinology of the Testis (BA Cooke, RM Sharpe, eds) Serono Symp Publ, Raven Press, NY, 50, 255-270

Kamtchouing P, Pinon-Lataillade G, Papadopoulos V, Guillaumin JM, Bardos P, Maas J, Perreau C, Drosdowsky MA, Hochereau-de Reviers MT, Carreau $S$ (1988) Effect of continuous low-dose $\gamma$-irradiation on rat Sertoli cell function. Reprod Nutr Dev 28, 10091017

Kangasniemi M, Kaipia A, Toppari J, Mali P, Huhtaniemi I, Parvinen M (1990a) Cellular regulation of basal and $\mathrm{FSH}$-stimulated cyclic AMP production in irradiated rat testes. Anat Rec 227, 32-36

Kangasniemi M, Kaipia A, Toppari J, Perheentupa A, Huhtaniemi I, Parvinen M (1990b) Cel- 
lular regulation of follicle-stimulating hormone (FSH) binding in rat seminiferous tubules. J Androl 11, 336-343

Leblond CP, Clermont Y (1952) Definition of the stages of the cycle of the seminiferous epithelium in the rat. Ann NY Acad Sci 55, 548573

Le Magueresse B, Jégou B (1988) In vitro effects of germ cells on the secretory activity of Sertoli cells recovered from rats of different ages. Endocrinology 122, 1672-1680

Le Magueresse B, Le Gac F, Loir M, Jégou B (1986) Stimulation of rat Sertoli cell secretory in vitro by germ cells and residual bodies. $J$ Reprod Fertil 77, 489-498

Le Magueresse B, Pineau C, Guillou F, Jégou B (1988) Influence of germ cells upon transferrin secretion by rat Sertoli cells in vitro. J En * docrinol 118, R13-R16

Main SJ, Davies RV, Young MGWL, Setchell BP (1976) Serum and pituitary gonadotrophins after destruction of germinal cells in the testis by X-irradiation or heat. J Endocrinol 69, 23P

Main SJ, Davies RV, Setchell BP (1978) Feedback control by the testis of gonadotrophin secretion: an examination of the inhibin hypothesis. J Endocrinol 79, 255-270

Meistrich ML, Hunter NR, Suzuki N, Trostle PK, Withers HR (1978) Gradual regeneration of mouse testicular stem cells after exposure to ionizing radiation. Radiat Res 74, 349-362

Oakberg EF, Di Minno RL (1960) X-ray sensitivity of primary spermatocytes of the mouse. Int J Radiat Bio/ 2, 196-209

Parvinen M (1982) Regulation of the seminiferous epithelium. Endocr Rev 3, 404-417

Pineau C, Velez de la Calle JF, Pinon-Lataillade G, Jégou B (1989) Assessment of testicular function after acute (neutron $+\gamma$ ) and chronic ( $\gamma$ ) irradiation: further evidence for an influence of late spermatids upon Sertoli cell function in the adult rat. Endocrinology 124, 2720-2728

Pinon-Lataillade G, Viguier-Martinez MC, Maas $J$ (1985) Endocrinological and histological changes induced by continuous low dose $\gamma$ irradiation of the rat testis. Acta Endocrinol $109,558-562$
Pinon-Lataillade G, Velez de la Calle JF, Viguier-Martinez MC, Garnier DH, Folliot R, Maas $J$, Jégou B (1988) Influence of germ cells upon Sertoli cells during continuous low-dose rate $\gamma$-irradiation of adult rats. Mol Cell Endocrinol 58, 51-63

Rich KA, de Kretser D (1977) Effect of differing degrees of destruction of the rat seminiferous epithelium on levels of serum folliclestimulating hormone and androgen bindingprotein. Endocrinology 101, 959-968

Rich KA, Kerr JB, de Kretser DM (1979) Evidence for Leydig cell dysfunction in rats with seminiferous tubule damage. Mol Cell Endocrinol 13, 123-135

Risbridger GP, Hodgson YM, de Kretser DM (1981a) Mechanism of action of gonadotrophins on the testis. In: The Testis (H Burger, DM de Kretser, eds) Raven Press, NY, 195211

Risbridger GP, Kerr JB, Peake RA, de Kretser DM (1981b) An assessment of Leydig cell function after bilateral or unilateral efferent duct ligation: further evidence for local control of Leydig cell function. Endocrinology 109, 1234-1241

Ritzén EM, French FS, Weddington SC, Nayieh SN, Hansson V (1974) Steroid binding in polyacrylamide gels. J Biol Chem 249, 65976604

Setchell BP, Davies RV, Main SJ (1977) Inhibin. In: The Testis (AD Johnson, WR Gomes, eds) Academic Press, NY, 4, 189-238

Sharpe RM (1986) Paracrine control of the testis. Clin Endocrinol Metab 15, 185-207

Shaver SL (1953) X-irradiation injury and repair in the germinal epithelium of male rats. $A m \mathrm{~J}$ Anat 92, 391-431

Tindall DJ, Vitale R, Means AR (1975) Androgen binding-protein as a biochemical marker of formation of the blood testis barrier. Endocrinology 97, 636-648

Van Beek MEAB, Davids JAG, de Rooij DG (1986) Non random distribution of mouse spermatogonial stem cells surviving fission neutron irradiation. Radiat Res 107, 11-23

Verhoeven G, Cailleau $J$ (1989) Tubule-Leydig cell interaction. In: Perspectives in Andrology 
(M Serio, ed), Serono Symp Publ, Raven Press, NY 53, 227-234

Viguier-Martinez MC (1976) Plasma LH response to LH-RH injection in immature intact castrated and cyproterone-treated male rats. J Reprod Fertil 48, 195-197

Viguier-Martinez MC, Hochereau-de Reviers MT, Barenton B, Perreau C (1983) Effect of a non-steroidal antiandrogen, flutamide, on the hypothalamo-pituitary axis, genital tract and testis in growing male rats: endocrinological and histological data. Acta Endocrinol 102, 299-306
Vihko KK, Suominen JJO, Parvinen M (1984) Cellular regulation of plasminogen activator secretion during spermatogenesis. Biol Reprod 31, 383-389

Wang J, Galil KAA, Setchell BP (1983) Changes in testicular blood flow and testosterone production during aspermatogenesis after irradiation. J Endocrinol 98, 35-46

Weinbauer GF, Bartlett JMS, Fingscheidt U, Tsonis CG, de Kretser DM, Nieschlag E (1989) Evidence for a major role of inhibin in the feedback control of FSH in the male rat. J Reprod Fertil 85, 355-362 